ACTA THERIOLOGICA

Vol. 24, 4: $47-59,1979$

\title{
Food Consumption and Energy Expenditure of the Field Vole in the Laboratory and in a Small Outdoor Enclosure
}

\author{
Peter N. FERNS
}

\begin{abstract}
Ferns P.N., 1979: Food consumption and energy expenditure of the field vole in the laboratory and in a small outdoor enclosure. Acta theriol., 24, 4: 47-59 [With 4 Tables].

The metabolic rate of Microtus agrestis (Linnaeus, 1761) was determined in one hour and 24 hour trials using an open circuit respirometer and gas analysis by gas chromatography. Respiration was higher (by about $30 \%$ for a $20 \mathrm{~g}$ vole at $10^{\circ} \mathrm{C}$ ) in the one hour trials, in which no food or bedding were provided. A 20 -fold increase in the size of the respiration chamber had no significant effect on the rate of metabolism. Food consumption was measured in four day trials on a diet of whole oats. The metabolic rate calculated from these feeding trials was very similar to that measured in the one hour respiration trials. The multiple regression equation relating digested energy (D) expressed in $\mathrm{kJ} / \mathrm{day}$, to temperature $(T)$ in ${ }^{\circ} \mathrm{K}$, body weight $(W)$ in $\mathrm{g}$, and weight change $(P)$ in g/day, was: $\log D=22.4842-8.7775 \log T+$ $\left.+0.6861 \log W+0.1002 \log P+\frac{1}{2}\right)$. This equation was found to predict the food consumption of voles in a small outdoor enclosure to within $2.2 \%$ at temperatures in the range $14-19^{\circ} \mathrm{C}$.

[Dept. Zool., Univ. College, Cathays Park, Cardiff, Wales, United
\end{abstract} Kingdom].

\section{INTRODUCTION}

During the course of a study of the energy flow through a population of field voles, Microtus agrestis ( $\mathrm{L}$ in n a e u s, 1761), inhabiting a young larch plantation in south west Britain, trials were conducted to determine the rates of food consumption and energy expenditure. Although the ultimate objective was to estimate vole metabolism in the field, the majority of these trials were conducted in the laboratory. Measurements were made under a variety of experimental conditions, and the results provide an opportunity to examine the effects of chamber size, trial duration, sex, temperature, body weigth and weight change on the rate of metabolism. Food consumption and respiration were measured in separate trials, but can be related to one another by the following energy balance equations (Petrusewicz, 1967): $C=F+$ $U+A ;$ and $A=P+R$; where $C=$ food consumption, $F=$ faeces production, $U=$ urinary excretion, $A=$ assimilation, $P=$ production and $R=$ respiration 
The object of this paper is to present equations relating the food consumption and respiration of $M$. agrestis to a range of independent variables, and to discuss the effects on metabolism of different experimental conditions, including those found in a small outdoor enclosure.

\section{MATERIALS AND METHODS}

The experimental stock was housed in individual plastic mouse cages in a room maintained at $10^{\circ} \mathrm{C}$ with an artificial daylength of 12 hours. Each cage was provided with an excess of food in the form of whole oats, and fresh greens were supplied at least three times a week. In order to preclude the possibility of long term metabolic acclimatisation to laboratory conditions (c.f. Górecki, 1966), all the feeding and respiration trials were conducted using voles which had been in captivity for less than six weeks.

Rates of respiration were measured in an open circuit respirometer employing gas analysis by gas chromatography. The chromatograph was a Pye Series 104 with a katharometer detector. Mineral helium was used as the carrier gas, and a molecular sieve column was employed to separate out oxygen, and a silica gel column to separate out carbon dioxide. The areas under the chromatograph peaks were measured with a Kent Chromalog digital integrator. The air passing through the respiration chamber was drawn from outside the laboratory window and fed through temperature equilibration coils adjacent to the chamber in a water bath. Air was propelled through the whole system, including the gas chromatograph injection valves and a gas meter, by means of a peristaltic flow inducer. The rate of flow was maintained at a level which ensured that the chamber effluent was approximately $1 \%$ diluted with respired air.

Initially, a series of one hour respiration trials were undertaken. These were intended to provide estimates of metabolism under conditions of high activity and so no food or water were supplied and no acclimatisation period was given. The respiration chamber consisted of a $1000 \mathrm{~cm}^{3}$ ground glass flask, placed on its side in a water bath. A series of 24 hour trials were subsequently conducted using the same chamber, but in this case chopped oats, potato segments and cotton wool nesting material were supplied, and a 24 hour acclimatisation period was given. During the latter trials, the chamber effluent was passed through a modified Gooderham gas sample holder in which the piston was sunk slowly by means of a small electric motor, thus providing an integrated sample of the effluent over the course of each 24 hour period. These samples were stored for later analysis. A small number of 24 hour respiration trials were also conducted using a $20 \mathrm{l}$ chamber which provided more space for the animal to move around in. This chamber was too large to be accommodated in a water bath and so the trials were conducted at room temperature.

Food consumtion was measured in the laboratory by means of a series of difference-trials using whole oats as the food source. Although the natural diet of $M$. agrestis consistis almost entirely of green plants (Hanson, 1971; Ferns, 1976), the high water content of such material makes it difficult to conduct the necessary weighings with sufficient accuracy. Oats present no such problem and have a further advantage in being so highly digestible that only small amounts of faecal material have to be sorted from the uneaten food. In these trials, voles were housed individually in plastic mouse stock cages with water supplied ad 
libitum, but without any nesting material. In most cases, the cages were placed in a constant temperature cabinet and two days of acclimatisation were allowed, followed by a four day experimental period. $100 \mathrm{~g}$ of whole oats were placed in each cage at the start of the four day period. At the end of each trial, uneaten food and faeces were dried to constant weighit, the former in a drying oven at $90^{\circ} \mathrm{C}$ and the latter in a vacuum oven at $60^{\circ} \mathrm{C}$.

Finally, several difference-trials were conducted in a small outdoor enclosure which provided animals with a much larger amount of space than any of the laboratory cages. It coverèd an area of $3.1 \times 2.2 \mathrm{~m}$ and was about $30 \mathrm{~cm}$ deep being completely enclosed in $1 \mathrm{~cm}$ mesh chicken wire. The enclosure was filled to a depth of $20 \mathrm{~cm}$ with peat moss to provide a suitable substrate for burrowing. This material was of no nutritive value to voles. Surface cover was provided in the form of shredded polythene and wood shavings. Since $M$. agrestis tends to store whole grains of oats, animals in the enclosure were provided daily with weighed amounts of rolled oats. This was placed in four metal boxes, each of which was stationed in a corner of the enclosure adjacent to a water bottle. Four voles were used per trial, each of them being introduced into one of the four metal boxes on the first day. The trials lasted for 12-14 days and the animals were captured in Longworth traps at the beginning, middle and end of each trial so that they could be weighed. The average temperature at the surface of the peat moss, under wood shavings, was measured by the sucrose inversion method of Berthet (1960).

The ash and energy content of food and faeces in each feeding trial was determined using a Gallenkamp ballistic bomb calorimeter (Miller \& Pay ne, 1959).

\section{RESULTS}

\section{Respiration}

Analysis of covariance showed that there were no significant differences in oxygen consumption between males and females in any of the respiration trials and so the results for both sexes have been combined. In the statistical analysis of results, the logarithm of temperature has been employed as an independent variable. This is justified because trials were conducted at temperatures below the thermoneutral zone, in a region where the response is effectively linear on a logarithmic scale (van't Hoff-Arrhenius equation). In the one hour trials, the slope of the least squares regression line relating the respiratory quotient to the logarithm of temperature was significantly different from zero $(t=2.53, p=0.01-0.02)$, though none of the other independent variables showed a similarly significant effect. The equation describing the above relationship was as follows.

$$
R Q=3.7612 \log T-8.4577
$$

(where, $R Q=$ respiratory quotient and $T=$ temperature ${ }^{\circ} \mathrm{K}$ ).

Equation (1) only accounts for $12 \%$ of the variability in $R Q$, so that although the regression is significant, the relationship is not a strong 
one. At $5^{\circ} \mathrm{C}$ the predicted $R Q$ is 0.74 , rising to 0.85 at $25^{\circ} \mathrm{C}$ (Table 1 ). In order to convert oxygen consumption data into the corresponding figures for energy expenditure, an assumed value for the non-protein $R Q$ has to be used (urinary nitrogen excretion was not measured in these trials). A single value of 0.80 was employed at all temperatures and the corresponding energetic equivalent of oxygen at this non-protein $R Q$ was utilised.

49 one hour trials were conducted, at temperatures between 2.6 and $25.6^{\circ} \mathrm{C}$, using voles ranging in weight from 10.6 to $29.6 \mathrm{~g}$. Weight change was not monitored. The rate of respiration showed a significant regression on both temperature $(t=-10.53, p<0.001)$ and body weight $(t=7.57, p<0.001)$, the former accounting for $53 \%$ of the variability in respiration, and the latter for $25 \%$. The regression equation was as follows.

$$
\begin{aligned}
\log R & =23.7342-9.8582 \log T+0.6798 \log W \\
& : \pm 0.0773)( \pm 0.9358) \quad( \pm 0.0898)
\end{aligned}
$$

(where $R=$ respiration in $\mathrm{kJ} /$ day, $T=$ temperature in ${ }^{\circ} \mathrm{K}, W=$ body weight in $\mathrm{g}$; the figure in brackets underneath the intercept $=$ the standard deviation of the estimate, and the figures underneath the slopes $=$ the standard deviations of the regression coefficients).

Table 1

Respiratory quotients in the one hour respiration trials, calculated from equation (1)

\begin{tabular}{rrrrc}
\hline Temperature $\left({ }^{\circ} \mathrm{C}\right)$ & 0 & 5 & 15 & 25 \\
\hline Respiratory quotient & 0.707 & 0.736 & 0.794 & 0.849 \\
\hline
\end{tabular}

Twenty eight 24 hour trials were conducted in the small chamber, including seven at $8.1^{\circ} \mathrm{C}$, eleven at $15.2^{\circ} \mathrm{C}$, and ten at $26.6^{\circ} \mathrm{C}$. In addition, ten trials were conducted in the large respiration chamber at an average temperature of $19.7^{\circ} \mathrm{C}$. An analysis of covariance revealed no significant difference between the results from the large and small chambers $\left(F_{1}, 35=0.41, p>0.10\right)$, and so the results from both have been combined. There was no significant correlation between the $R Q$ and any of the independent variables, and a non-protein value of 0.80 was again assumed. The rate of respiration showed a significant regression on temperature $(t=-3.17, \quad p=0.001-0.010)$ and vole weight ( $t=3.37, p=0.001-0.010)$ but not on weigth change, which was an additional variable in these trials $(t=-0.78, p>0.10)$. The latter variable was thus excluded from the calculations, leaving the following regression equation: 
$\log R=12.8093-5.4055 \log T+0.5981 \log W$

$$
( \pm 0.1065)( \pm 1.7046) \quad( \pm 0.1778)
$$

(symbols as in equation (2)).

\section{Digested Energy}

The feeding trials on whole oats in the laboratory were comprised of twelve replicates at $3.1^{\circ} \mathrm{C}$, fifteen at $6.7^{\circ} \mathrm{C}$, fifteen at $10.6^{\circ}$, eighteen at $13.8^{\circ} \mathrm{C}$ seven at $16.5^{\circ} \mathrm{C}$ and seven at $20^{\circ} \mathrm{C}$, making a total of 74 four day trials. Samples of the faeces produced at each temperature were taken from the pooled residue of all replicates after grinding, for determination of their energy content. The energy based coefficients of digestiblility (Table 2) were similar in all the trials above $10^{\circ} \mathrm{C}$, but below this temperature, the digestibility of whole oats began to decline. This effect was confirmed by a multiple regression analysis which showed that $29 \%$ of the variability in the digestibility of whole oats was accounted for by temperature with vole weight and weight change exerting no significant influence.

The digested energy was then regressed against temperature, body weight and weight gain. The latter was sometimes negative (i.e. weight was lost), and it thus had to be coded by the addition of half a gram in order to allow a logarithmic transformation to be employed. All three variables had regression coefficients which were significantly different from zero, with temperature accounting for $40 \%$ of the variability in digested energy, body weight for $30 \%$ and weight change for $14 \%$. The regression equation was as follows.

$$
\begin{gathered}
\log D=22.4842-8.7775 \log T+0.6861 \log W+0.1002 \log \left(P+\frac{1}{2}\right) \\
( \pm 0.0332)( \pm 0.6703) \quad( \pm 0.0492) \quad( \pm 0.0193)
\end{gathered}
$$

(where $D=$ digested energy in $\mathrm{kJ} /$ day, $P=$ weight change in $\mathrm{g} /$ day, other symbols as in equation (2)).

Eight voles weighing between 17 and $25 \mathrm{~g}$ were fed on rolled oats at $15^{\circ} \mathrm{C}$ for a few days to compare the coefficient of digestibility with that of whole oats. The average coefficient with one standard deviation was $91.9 \pm 3.1 \%$. This is a trifle higher than the figure for whole oats, but not significantly so.

\section{Enclosure Trials}

A total of four enclosure trials, lasting for 12, 12, 13 and 14 days, were conducted. The only complicating factor which arose during the interpretation of the results involved the two occasions when an animal died during the course of a trial. It was, however, relatively easy to determine the days upon which these deaths occurred, because they 
were marked by a sudden drop in food consumption. The corpses of both animals were eventually recovered and they showed injuries which were consistent with the cause of death being social conflict, rather than starvation.

Table 2

Observed coefficients of digestibility in each of the four day feeding trials on whole oats (mean \pm S.D.).

\begin{tabular}{lcccccc}
\hline Temperature of trial $\left({ }^{\circ} \mathrm{C}\right)$ & 3.1 & 6.7 & 10.6 & 13.8 & 16.5 & 20.0 \\
\hline Coeff. of digestibility $(\%)$ & $83.3 \pm 6.1$ & $86.7 \pm 7.0$ & $9.2 \pm 5.2$ & $90.6 \pm 4.6$ & $89.1 \pm 4.5$ & $90.5 \pm 3.7$
\end{tabular}

Since individual voles could have used more than one feeding station, it was not possible to monitor individual rates of food consumption in these trials. The results were therefore analysed in the following way. Predicted values for digested energy were calculated for each half trial using equation (4) and substituting the observed values of $T, W$ and $P$ for each animal. When divided by the energy content $(19.99 \mathrm{~kJ} / \mathrm{g})$ and the digestibility (0.919) of rolled oats, these values gave predicted overall figures for food consumption which could be compared with the observed figures (Table 3).

Table 3

Comparison between the observed consumption of rolled oats in the enclosure trials and the expected consumption based on the four day feeding trials in the laboratory.

\begin{tabular}{|c|c|c|c|c|c|}
\hline & $\begin{array}{l}\text { Number } \\
\text { of vole } \\
\text { days }\end{array}$ & $\begin{array}{l}\text { Mean } \\
\text { temp. } \\
\left({ }^{\circ} \mathrm{C}\right)\end{array}$ & $\begin{array}{l}\text { Observed food } \\
\text { consumption } \\
\text { (g dry weight) }\end{array}$ & $\begin{array}{l}\text { Expected food } \\
\text { consumption } \\
\text { (equation (4)) }\end{array}$ & Difference \\
\hline \multicolumn{6}{|l|}{ Trial 1} \\
\hline First half & 20 & 16.5 & 57.80 & 49.88 & -7.92 \\
\hline $\begin{array}{r}\text { Second half } \\
\text { Trial } 2\end{array}$ & 28 & 19.0 & 83.95 & 73.64 & -10.49 \\
\hline First half & 24 & 16.4 & 66.25 & 61.31 & -4.94 \\
\hline $\begin{array}{r}\text { Second half } \\
\text { Trial } 3\end{array}$ & 21 & 15.7 & 62.65 & 58.45 & -4.20 \\
\hline First half & 24 & 14.5 & 68.85 & 62.52 & -6.33 \\
\hline $\begin{array}{r}\text { Second half } \\
\text { Trial } 4\end{array}$ & 28 & 17.3 & 76.66 & 75.23 & -1.43 \\
\hline First half & 28 & 14.0 & 70.36 & 87.94 & +17.58 \\
\hline Second half & 23 & 14.7 & 64.06 & 70.16 & +6.10 \\
\hline Total & 196 & & 550.58 & 538.95 & -11.63 \\
\hline
\end{tabular}

It is apparent from Table 3 that the difference between observed and predicted values is quite small. On average, equation (4) overestimated food consumption by $2.2 \%$. The thermal economies afforded by nestbuilding (and possibly huddling), which were only possible in the enclosure, appear to have been at least partially offset by the extra 
energy expenditure incurred during greater activity. However, the range of temperatures studied was quite small $\left(14-19^{\circ} \mathrm{C}\right)$, and the difference between observed and expected values does show a negative correlation with temperature which verges on significance $(r=-0.67$, $p \simeq 0.05$ ). This suggests that equation (4) might not be such an accurate predictor of food consumption outside this range of temperatures.

\section{Comparison between Laboratory Estimates}

Predicted daily rates of respiration of voles of selected body weights at some typical temperatures encountered in the field, are shown in Table 4. In order to enable these to be compared with the results from the feeding trials, estimates of digested energy obtained from equation (4) have to be corrected for energy losses in urine, and for growth. No measurements of urinary energy loss were made for $M$. agrestis and so an approximation has had to be made, based on results obtained by D r o ż d ż (1968) for $M$. arvalis. Drożdż found that, on average, $2.82 \%$ of the digested energy of whole oats was excreted, and so the predicted values of $D$ from equation (4) were reduced by this amount.

Table 4

Calculated daily rates of energy expenditure in $\mathrm{kJ}$, based on laboratory trials. $A-$ one hour respiration trials (equation (2)); $B-$ one day respiration trials (equation (3)); C - four day feeding trials (see text).

\begin{tabular}{ccccc}
\hline $\begin{array}{c}\text { Body } \\
\text { weight }(\mathrm{g})\end{array}$ & $\begin{array}{c}\text { Type of } \\
\text { estimate }\end{array}$ & 0 & $\begin{array}{c}\text { Temperature }\left({ }^{\circ} \mathrm{C}\right) \\
10\end{array}$ & 20 \\
\hline \multirow{2}{*}{10} & $A$ & 59.5 & 41.8 & 29.7 \\
& $B$ & 41.4 & 34.1 & 28.3 \\
\multirow{2}{*}{20} & $C$ & 55.1 & 40.2 & 29.6 \\
& $A$ & 95.6 & 66.9 & 47.5 \\
\multirow{3}{*}{30} & $B$ & 62.7 & 51.6 & 42.8 \\
& $C$ & 86.7 & 64.7 & 47.7 \\
& $A$ & 125.6 & 88.2 & 62.6 \\
& $B$ & 79.9 & 59.3 & 54.5 \\
& $C$ & 116.9 & 85.4 & 63.0 \\
\hline
\end{tabular}

In order to correct for growth, the value of $P$ in equation (4) was set at zero. Provided that the observed changes in weight during the four day feeding trials were due to the deposition or catobolism of materials with the same energy contens as the rest of the body, this procedure is satisfactory. If, however, such weight changes were due to changes in the water content or fat content of the body (M e e s e, 1971), then

- errors may arise. Wild caught animals brought into the laboratory often show rapid changes in both fat and water content (F e r n s \& A da m s, 1974). The voles in the feeding trials had, however, been maintained on the same diet and under the same conditions for several weeks and 
thus it is reasonable to assume that only normal growth was taking place (the maximum rate of $0.4 \mathrm{~g} /$ day was very similar to the peak rates recorded in the field).

It is clear from Table 4 that the results of the one hour respiration trials and the four day feeding trials are in good agreement, especially at the higher temperatures. The 24 hour trials, on the other hand, gave results which are $10-30 \%$ lower. Both the temperature and the body weight exponents are lowest in equation (3), which relates to the 24 hour trials. The body weight exponents in the one hour and four day trials ( 0.68 and 0.69 respectively) are very close to the theoretical values for heat production based on calculations of the surface area of the body in mammals (H e n s e l, B r ück \& R a ths, 1973). However, they are smaller than the three quarters power of body weight which has been found experimentally to be the metabolically effective body size (K le i b e r, 1961; P oczopko, 1971). No doubt this difference is partly explained by the fact that the trials on $M$. agrestis were not conducted at thermoneutral temperatures. The exponents are in fact comparable to those obtained for similar species below the thermoneutral zone (e.g. Wi e g e r t, 1961; Hannson \& Grodziński, 1970). When nesting material was present ( 24 hour respiration trials only), the experimental voles did have the opportunity of reducing heat loss from the body by constructing well insulated nests. This they readily did, and in consequence the body weight exponent fell to 0.60. The effect of nest building on the temperature exponent was even more marked, since this declined from -9.86 in the one hour trials, to -8.78 in the four day trials, and -5.41 in the 24 hour trials. These differences emphasize the importance of behavioural strategies, such as nest building, in maximising thermal economy in homoiothermic animals.

\section{DISCUSSION}

The fact that temperature exerted a significant influence on $R Q$ in the one hour respiration trials is an unusual finding which requires some explanation. The $R Q$ in question is not a nonprotein value, but this in itself cannot be the explanation of the downward trend in $R Q$ with increasing temperature (Table 1), since the $R Q$ of mixed protein is about $0.8: 0$, a figure which is very close to typical non-protein values. However, the oxidation of mixed fats yields an $R Q$ of about 0.71 and it thus seems probable that voles were metabolising mainly lipids at the lower temperatures in the one hour trials. Rapid mobilisation of depot lipid represents an early response of the body to sudden cold exposure. This initial response may have been modifiel later, since $R Q$ 's were not significantly reduced at low temperatures in the 
24 hour trials. Alternatively, the provision of nesting material may have confounded any long term effect of temperature on $R Q$.

The coefficient of digestibility of whole oats $(91 \%)$ was very close to the value obtained for $M$. arvalis $(92 \%)$ at $20^{\circ} \mathrm{C}$ by $\mathrm{D} \mathrm{r}$ o ż d $\dot{\mathrm{z}}(1968)$. Natural foods, such as grasses, are of course much less digestible than this, because of their higher fibre content ( $\mathrm{H}$ a n s S o n, 1971). Even on whole oats, there was a marked decline in the coefficient of digestibility below $10^{\circ} \mathrm{C}$ in the present feeding trials. Presumably a threshold existed, below which the energy demands of thermoregulation became so great that food had to be passed through the digestive tract too rapidly for normal digestion and absorption to occur. This threshold was well within the normal range of temperatures encountered in the field. Furthermore, this effect is likely to be more severe for animals consuming the bulkier, less digestible foods which from most of the natural diet.

The size of the cage or chamber used in the respiration and feeding trials seemed to have little influence on the rate of metabolism. The length of the trial period was also relatively unimportant. On the other hand, the provision of nesting material did have an important influence in reducing the overall rate of metabolism. The one hour respiration trials, the four-day feeding trials, and the longer term enclosure trials showed remarkably close agreement at the range of temperatures common to all three $\left(14-19^{\circ} \mathrm{C}\right)$. It is, however, the lower temperatures which are particularly important since the average fornightly mean temperatures in vole runways in the field (measured by Berthet's (1960) method) covered the range $0.8-16.6^{\circ} \mathrm{C}$.

The rates of respiration measured in the one hour trials show quite a close agreement with previously published values for other Microtus species (H a t field, 1939; P earson, 1947; Morrison, 1948; Jáns ký, 1959, G oll e y, 1960; W i e ger t, 1961; G rodziński, 1961; Riga u dièr e \& $\mathrm{D}$ elo $\mathrm{s} t, 1964 ; \mathrm{P} a \mathrm{c} k \mathrm{ard}$, 1968). Such short term respiration measurements have often been referred to as $R M R s$ (resting metabolic rates). This can be confusing because such rates are often greater than the $A D M R$ (average daily metabolic rate), measured under the same conditions, even though the latter should include $R M R$ plus extra metabolic expenditure for activity. It is apparent that during the initial stages of confinement in respiration chambers, metabolic rates are often elevated because of the stress of the new environment.

In a series of one hour respiration trials on $M$. agrestis, $\mathrm{H}$ an s son \& Grodziński (1970) recorded a metabolic rate for c. $20 \mathrm{~g}$ animals of $33.1 \mathrm{~kJ} /$ day at $30^{\circ} \mathrm{C}$ and $84.8 \mathrm{~kJ} /$ day at $5^{\circ} \mathrm{C}$. These results are very close to those of the one hour trials in Table 4, and the temperature 
exponent was -10 in both cases. Solitary animals had a metabolic rate of $38.8 \mathrm{~kJ} /$ day at $20^{\circ} \mathrm{C}$ when measured over a 24 hour period by $\mathrm{H}$ ans son \& Grodziński (1970), which compares with $42.8 \mathrm{~kJ} /$ day in Table 4. Despite the good agreement between these results, differences in interpretation can lead to considerable variation in the methods used to calculate daily energy budgets $(D E B)$. For example, using their 24 hour trials, and applying corrections for out of the nest thermoregulation and the extra energetic costs of reproduction, $\mathrm{Hans}$ a $\mathrm{n}$ \& Grodziński (1970) derive an equation for the summer $\left(20^{\circ} \mathrm{C}\right) \mathrm{DEB}$ which yields a value of $47.3 \mathrm{~kJ} /$ day for a $20 \mathrm{~g}$ vole. This is very close to the $47.7 \mathrm{~kJ} /$ day calculated from equation (4) and corrected for excretion. On the other hand, their equation for the $D E B$ in winter $\left(2^{\circ} \mathrm{C}\right)$ gives a value of $43.8 \mathrm{~kJ} /$ day for a $20 \mathrm{~g}$ animal, which is only about half the $83.3 \mathrm{~kJ} /$ day calculated directly from equation (4). The reason for this large discrepancy is that the use of equation (4) is based on the premise that the thermal economies afforded by nest building are more or less couterbalanced by the extra energy expenditure involved in increased activity in the field, whereas Hansson \& Grodziński assumed that voles spend only $24 \%$ of their time out of the nest and are thus subjected to low winter temperatures for only a short period. The figure of $24 \%$ was based on activity an a respirometer in which food was supplied freely and no account was therefore taken of the time which would be spent on foraging for this food in the field. Similarly low levels of activity have been used in calculating the $D E B$ of other Microtus spp. (e.g. Grodziński \& Górecki, 1967; Tro$\mathrm{j}$ a $\mathrm{n}, 1969)$. It is unfortunate that the enclosure trials in the present study only provide a test of the predicted metabolic rates at temperatures at which there is already a good agreement between the estimates of $D E B$. However, since it is the duration of activity, rather than the level of energy expenditure during activity, which gives rise to the discrepancy at low temepratures, in would be very useful to obtain some measurements of natural activity periods in the field. This conclusion was also reached by Grodziński \& Wunder (1975). Suitable measurements could be made using automatically recording thermistor probes placed in natural nests ( $\mathrm{F} \mathrm{low}$ e r dew, 1973). It is interesting that the single 24 hour recording of a $M$. agrestis nest shown by Flowerdew is of an animal active for $59 \%$ of the time in March. Really accurate tests of predicted $D E B S$ will have to await more widespread use of the $\mathrm{D}_{2}{ }^{18} \mathrm{O}$ method for measuring the metabolism of free living animals. At least one such test has already been made for Perognathus formosus (M ulle $\mathrm{n} \& \mathrm{Chew}, 1973$ ). It was found that 
the $D E B$ calculated from laboratory data ( $\mathrm{Chew} \& \mathrm{Chew}, 1970)$ underestimated field metabolism by about $12 \%$ in this desert species.

Acknowledgements: This work was supported by the Science Research Council. I would like to thank G.G. Vickers and I.J. Linn for their guidance, and Professors L.A. Harvey and D. Bellamy for facilities at Exeter and Cardiff.

\section{REFERENCES}

1. Berthet P., 1960: La mesure écologique de la température par détermination de la vitesse d'inversion due succharose. Vegetatio, 9: 197-207.

2. Chew R.M. \& Chew A.E., 1970: Energy relationships of the mammals of a desert shrub (Larrea tridentata) community. Ecol. Monogr., 40: 1-21.

3. Drożd ̇ A., 1968: Digestibility and assimilation of natural foods in small rodents. Acta theriol., 13: 367-389.

4. Ferns P.N., 1976: Diet of a Microtus agrestis population in south west Britain. Oikos, 27: 506-511.

5. Ferns P.N. \& Adams M., 1974: The effects of laboratory confinement on lipid deposition in Wood mice, Bank voles and Field voles. J. Zool., Lond., 174: $524-528$.

6. Flowerdew J.R., 1973: A new method for recording the activity of small mammals in the field. J. Zool., Lond., 171: 449-455.

7. Golley F.B., 1960: Energy dynamics of a food chain of an old-field community. Ecol. Monogr., 30: 187-206.

8. Górecki A., 1966: Metabolic acclimatization of bank voles to the laboratory conditions. Acta theriol, 11: 399-407.

9. Grodziński W., 1961: Metabolism rate and bioenergetics of small rodents from the deciduous forest. Bull. Acad. Pol. Sci. Cl. II., 9: 493-499.

10. Grodziński W. \& Górecki A., 1967: Daily energy budgets of small rodents. [In: »Secondary productivity of terrestrial ecosystems (principles and methods«, Ed. K. Petrusewicz]. 1: 295-314. Państw. Wyd. Nauk., Warszawa - Kraków.

11. Grodziński W. \& Wunder B.A., 1975: Ecological energetics of small mammals. [In: »Small mammals: their productivity and population dynamies" Eds. Golley F.B. Petrusewicz K. \& Ryszkowski L.]: 173-204. Cambridge University Press, Cambridge.

12. Hansson L., 1971: Habitat, food and population dynamics of the field vole Microtus agrestis (L.) in south Sweden. Viltrevy, 8: 267-378.

13. Hansson L. \& Grodzieński W., 1970: Bioenergetic parameters of the field vole Microtus agrestis L. Oikos, 21: $76-82$.

14. Hatfield D.M., 1939: Rate of metabolism in Microtus and Perymyscus. Murrelet, 20: $54-56$.

15. Hensel H., Brück K. \& $\mathrm{Rath}$ s P., 1973: Homeothermic organisms. [In: »Temperature and life « Eds. Precht H., Christophersen J., Hensel H. \& Larcher W.]: 503-761. Springer-Verlag, Berlin - Heidelberg - New York.

16. Jánský L., 1959: Working oxygen consumption in two species of wild rodents (Microtus arvalis, Clethrionomys glareolus). Physiologia bohemoslov., 7: $427-478$.

17. Kle iber M., 1961: The fire of life. J. Wiley \& Sons: $1-454$, London - New York. 
18. Me ese G.B., 1971: Some aspects of energy balance in the Bank vole Clethrionomys glareolus. J. Zool., Lond., 163: 305-317.

19. Mille r D.S. \& Pa yne P.A., 1959: Ballistic bomb calorimeter. Br. J. Nutr., 13: $501-508$.

20. Morrison P.R., 1948: Oxygen consumption in several small wild mammals. J. cell. comp. Physiol., 31: 69-96.

21. Mullen R.K. \& Chew R.M., 1973: Estimating the energy metabolism of free-living Perognathus formosus: a comparison of direct and indirect methods. Ecology, 54: $633-637$.

22. Packard G.C., 1968: Oxygen consumption of Microtus montanus in relation to ambient temperature. J. Mammal., 49: 215-220.

23. Pearson O.P., 1947: The rate of metabolism of some small mammals. Ecology, 28: 127-145.

24. Petrusewicz K., 1967: Concepts in studies on the secondary productivity of terrestrial ecosystems. [In: „Secondary productivity of terrestrial ecosystems (principles and methods)« Ed. K. Petrusewicz]. 1: 17-49. Państw. Wyd. Nauk., Warszawa-Kraków.

25. Poczopko P., 1971: Metabolic levels in adult homeotherms. Acta theriol., 16: $1-21$.

26. R ig a u dière N. \& Delost P., 1964: Point de neutralité et métabolisme de base chez les campagnols. J. Physiol,, Lond., 56: 431-432.

27. Trojan P., 1969: Energy flow through a population of Microtus arvalis (Pall.) in an agrocenosis during a period of mass occurrence. [In: »Energy flow through small mammal populations Eds. Petrusewicz K. \& Ryszkowski L.]: 267-279. Państw. Wyd. Nauk., Warszawa.

28. W i e gert R.G., 1961: Respiratory energy loss and activity patterns in the meadow vole Microtus pennsylvanicus pennsylvanicus. Ecology, 42: 245-253.

Accepted, September 20, 1978.

Peter N. FERNS

\section{ZAPOTRZEBOWANIE POKARMOWE I WYDATKI ENERGETYCZNE MICROTUS AGRESTIS ŻYJĄCYCH W LABORATORIUM I W MAEYCH ZAGRODACH}

Streszczenie

Tempo metabolizmu $M$. agrestis pochodzących z poludniowo-zachodniej Anglii było oznaczane w 1- i 24-godzinnych doświadczeniach, przy użyciu respirometru typu otwartego. Gaz analizowano chromatograficznie. W doświadozeniach 1-godzinnych, w których zwierzęta pozbawione były wody i pokarmu, oddychanie jest intensywniejsze (o około $30 \%$ u 20 -gramowych norników, w temperaturze $10^{\circ} \mathrm{C}$ ). Współczynnik oddechowy w eksperymentach 1-godzinnych wykazuje istotną pozytywną korelację z temperaturą (Tabela 1), zależność ta została opisana wzorem:

$$
R Q=3.7612 \log T-8.4577
$$

gdzie $R Q=$ współczynnik oddechowy, $T=$ temperatura $\left.\quad \mathrm{W}{ }^{\circ} \mathrm{K}\right)$. W obu typach doświadczeń (1- i 24-godzinnych) tempo zużycia tlenu było na istotnym poziomie 
skorelowane zarówno $\mathrm{z}$ temperaturą jak i ciężarem ciała (W) wyrażonym w $\mathrm{g}$. Zależnośoi te opisano następującymi wzorami:

$$
\log R=23.7342-9.8582 \log T+0.6798 \log W
$$

(gdzie $R=$ tempo respiracji w 1 -godzinnych doświadezeniach wyrażone $\mathrm{w} \mathrm{kJ} /$ dobę).

$$
\log R=12.8093-5.4055 \log T+0.5981 \log W
$$

(gdzie $R$ =oddychanie w 24-godzinnych doświadczeniach wyrażone $\mathrm{w} \mathrm{kJ} / \mathrm{dzień}$ ). Dwudziestokrotne zwiększenie rozmiarów komory respiracyjnej nie wplywa w istotnym stopniu na zwiększenie tempa metabolizmu.

Zapotrzebowanie pokarmowe mierzono w malych, indywidualnych klatkach pozbawionych materiału gniazdowego. Zwierzęta karmiono owsem. Wyniki 74-dniowych doświadczeń pokarmowych podsumowano następującym równaniem:

$$
\log D=22.4842-8.7775 \log T+0.6861 \log W+0.1002 \log \left(P+\frac{1}{2}\right)
$$

(gdzie $D=$ energia strawna wyrażona $\mathrm{w} \mathrm{kJ} /$ dzień, $P=$ zmiany ciężaru ciała w g/dobę). Przy temperaturach ponad $10^{\circ} \mathrm{C}$ współczynnik strawności owsa wynosi około $90 \%$, natomiast $\mathrm{w}$ niższych temperaturach współczynnik ten ma niższe wartości (Tabela 2).

Tempo metabolizmu teoretycznie obliczone $\mathrm{z}$ równania (4) jest bardziej zbliżone do wyników dobowych pomiarów respiracji niż do pomiarów uzyskanych w eksperymentach 24-godzinnych (Tabela 4). To samo równanie użyto do szacowania ilości pokarmu zjadanego przez norniki trzymane $w$ małych zagrodach (dokładność $2.2^{\%}$ ) w zakresie temperatur $14-19^{\circ} \mathrm{C}$ (Tabela 3.). W zagrodach nie przeprowadzano doświadczeń w niższych temperaturach od tego zakresu, tak więc ścisłość równania (4), do przewidywania energii strawnej w terenie $\mathrm{w}$ temperaturach niższych, nie może być oceniona. Zasugerowano jednak, że pewne równania służące do przewidywania dziennego budżetu energetycznego u Microtus zimą mogą dawać wartości zbyt małe, ponieważ opierają się one na laboratoryjnym szacowaniu okresów aktywności, które mogą być zbyt krótkie. 